\title{
A Syllabus-based Review of Collegiate Arboriculture Course Content in the United States
}

\author{
P. Eric Wiseman, Joseph W. Hoffman, Susan D. Day, and Terry L. Clements
}

\begin{abstract}
The professional skills and expertise demanded of practicing arborists are greater than at any time in the past, and many employers and educators believe that higher education plays a role in educating future professionals in this field. Although recent surveys have identified major instructional topics that are critically important for future arborists, no assessment of whether these topics are being taught in college and university programs is available. The following paper is a syllabus-level assessment of 68 arboriculture courses being taught at U.S. institutions of higher education. The most common instructional topics observed in syllabi of arboriculture courses at both two- and four-year institutions were pruning (85\%), disorders (81\%), physiology/biology (79\%), risks/hazards (79\%), and soils/nutrition $(75 \%)$. Tree planting and tree selection, topics identified by educators and public sector employers in previous studies as among the most important instructional areas, were found only in $74 \%$ and $62 \%$ of course syllabi, respectively. Safety was mentioned in only 53\% of syllabi. Syllabus content was similar at two-year and four-year institutions, although tree identification and arborist certification were mentioned more frequently in two-year institution syllabi. Trends in arboriculture education and implications for employers and professionals are discussed.

Key Words. Arboriculture Education; Arborist Training; Course Objectives; Educational Assessment.
\end{abstract}

Demand for arboriculture services (and thus employees) in the United States has shown strong growth over the last two decades. O'Bryan et al. (2007) performed a detailed assessment of the U.S. arboriculture industry for the period 1992-2002. At that time, they estimated the industry comprised nearly 82,000 establishments, employed about 160,000 workers (public and private sector), and earned annual gross receipts of nearly USD $\$ 9$ billion. According to the researchers, annual growth in arboriculture employment and revenues was nearly 20\% between 1997 and 2002. In its 2010 2011 Occupational Outlook Handbook, the U.S. Bureau of Labor Statistics (BLS) estimated 2008 employment in the tree trimmers and pruners occupational category at 45,000 people nationwide (Bureau of Labor Statistics 2010). The BLS report further predicted that employment in this occupational category should grow about $26 \%$ over the next eight years, adding nearly 12,000 new production employees to the arboriculture professional ranks.

Although the basic occupational duties of future arborists will likely resemble those of arborists practicing today, these duties will be carried out in the context of advancements in tree care science, sophistications in tree care technology, and increasing public awareness of proper tree care. As a result, it seems likely that there will be greater demand for well-educated, highly-skilled employees in the arboriculture industry over the next decade. Trends in the expectations of employers support this notion. A mid-1980s survey of arboriculture employers in the U.S. Mountain West region found that less than one-third of respondents desired a four-year degree for arborist employees (McPherson 1984). Nearly two decades later, a survey conducted in the Pennsylvania-Delaware Chapter of the International Society of Arboriculture (ISA) revealed that $70 \%$ of surveyed ar- boriculture firms felt that a bachelor's degree was important for certain positions (Penn-Del Chapter 2001). In the mid-2000s, Elmendorf et al. (2005) reviewed more than sixty years of literature on arboriculture education as well as several employer/ educator surveys, leading them to surmise that "the demand for arboriculture and urban forestry graduates remains high, and in many areas of the United States, demand exceeds the supply of available graduates." To keep pace with emerging challenges and expectations in the arboriculture profession, it is likely that arborists will increasingly rely upon post-secondary education to succeed in the 21 st century workplace. Yet there is no comprehensive understanding of collegiate arboriculture education in the U.S. This information is critical for framing discussions of the higher education needs of aspiring arborists and for refining collegiate arboriculture courses to meet those needs.

In the United States, there is no prevailing standard for collegiate arboriculture education. Although ISA sets clear expectations for arborist competencies in its professional certification programs, the organization does not evaluate or accredit collegiate arboriculture programs. In 2007, the Society of American Foresters (SAF) instituted a specialized accreditation for collegiate urban forestry programs (Society of American Foresters 2010). This accreditation has a broad disciplinary scope and addresses arboriculture as a component of urban forestry education rather than its focal point. Although SAF accreditation has historically focused on programmatic elements (e.g., facilities, instructor qualifications, funding), curricular content has been scrutinized on several occasions over the last 50-60 years, resulting in a narrowing of disciplinary focus (Green 2006). Nonetheless, it is unclear whether urban forestry accreditation by the SAF will have a significant im- 
pact on the curricular content of collegiate arboriculture education in the future. Thus, even though educators have a tendency to agree on the fundamental aspects of arboriculture education (see discussion of Elmendorf et al. 2005), arboriculture course content is certainly not standardized, and may be more a function of an instructor's education and training, personal experiences, and preferences.

Over the last few decades, the literature on arboriculture education has focused more on describing programmatic structure and educational perceptions than on evaluating the content of curricula and courses. During the 1970s, the literature documented the expansion of collegiate urban forestry and arboriculture programs (Andresen and Williams 1975; Andresen 1977; King 1977). By 1975, at least 52 North American universities were offering arboriculture-oriented courses (Andresen 1977). Deneke (1978) provided curriculum content recommendations for collegiate urban forestry programs, and Ryan (1979) described four arboriculture courses offered by the State University of New York at Farmingdale. Surveys conducted during 1979-1980 identified 19 arboriculture courses and 12 arboriculture curricula being offered at 27 North American universities (Andresen 1981). In the mid-1980s, a survey of arboriculture employers revealed that private sector employers ranked tree surgery, tree pruning/removal techniques, cabling/bracing, equipment operation, and fertilization techniques as the most important skills of graduates from arboriculture programs (McPherson 1984). In contrast, public sector employers ranked equipment operation and cabling/bracing lower and instead emphasized the need for knowledge on planting techniques and insect/disease control. Occasional reviews of collegiate urban forestry programs were published in the 1990s (Hildebrandt et al. 1991; Hildebrandt et al. 1993; Rodbell 1993; Miller 1994; Sydnor 1997). Although these reviews provided some insights, primarily on urban forestry education, they did not explicitly analyze curricula or courses.

In 2003, ISA funded a survey of 136 collegiate arboriculture and urban forestry educators in the U.S. (Elmendorf et al. 2005). One of the survey's goals was to ascertain educators' attitudes about educational topics. According to the survey, the five most important educational topics were tree planting, tree pruning, tree selection, tree soil and water relations, and tree structure and decay identification ( $>90 \%$ of respondents considered each topic to be "very important"). When asked to rate the adequacy of instruction on these top-five topics, $77 \%-90 \%$ of the respondents agreed or strongly agreed that topical instruction was adequate. In comparing their findings to the survey work of McPherson (1984) 19 years earlier, the researchers surmised that "there is fairly consistent agreement about important arboricultural topics and their provision" (Elmendorf et al. 2005). While this work provided much needed insight on the perceptions of arboriculture educators, it did not include an assessment of arboriculture course content. To help fill this gap, the authors of the current research undertook a study to ascertain how well the content of collegiate arboriculture courses in the U.S. aligns with the expectations of employers and perceptions of educators as documented by McPherson (1984), Penn-Del Chapter (2001), and Elmendorf et al. (2005). To answer this question, an exhaustive search of online course descriptions was first conducted, followed by more detailed analysis of course syllabi provided by instructors. The objectives were to identify topics being taught in undergraduate arboriculture courses, rank their frequency of occurrence, and identify trends in arboriculture course content. This assessment provides a foundation for future discussions of arboriculture education at colleges and universities in the United States.

\section{MATERIALS AND METHODS}

\section{Course Description Assessment}

In early 2008, a preliminary review of online course catalogs from 279 U.S. colleges offering degrees in forestry, horticulture, and related disciplines was conducted to identify undergraduate arboriculture courses. The pool of colleges was synthesized from listings provided by ISA (ISA 2008), Tree Care Industry Association (TCIA 2008), and Davey Tree Expert Company (M. Noark, pers. comm.). The review identified 94 institutions (both two-year and four-year programs) offering a course with arboriculture in its title. Because some colleges offered more than one arboriculture course, a total 109 courses were inventoried. Next, the online catalog description of each course was reviewed to identify and enumerate topics being taught in the course. To do this, keywords found in each course description were classified into major topical categories, and the frequency of occurrence of these topics was then tabulated. Topic frequency was calculated as the percentage of course descriptions containing the topical keywords.

\section{Course Syllabus Assessment}

Course descriptions in online catalogs may not be updated regularly, but course syllabi are invariably updated yearly to more accurately reflect course content. As a result, a syllabus-level assessment of the arboriculture courses identified during the preliminary research was conducted. The syllabus is a document prepared by an instructor that itemizes course objectives, content, policies, activities, and assessments (Parkes and Harris 2002). This document is distributed to students at the beginning of a course and serves as both a contract and learning tool.

In January 2009, the colleges offering the 109 previously identified arboriculture courses were contacted to identify course instructors and request course syllabi. During this process, two additional collegiate programs surfaced, bringing the total count of colleges offering a course with arboriculture in the title to 96. Fourteen of these colleges did not respond to requests for instructor contact information and nine institutions had cancelled their arboriculture programs and/or courses. Thus, 73 arboriculture instructors were contacted to request copies of their course syllabi (Appendix). Syllabi for 68 courses (41 from two-year programs and 27 from four-year programs) taught by 59 instructors were obtained by the March 2009 submission deadline.

As in the course description assessment, each syllabus was reviewed to identify and enumerate topics being taught in the courses. Instructional topics were itemized based on topical keywords found in the syllabi and then classified as either major, supportive, or miscellaneous topics depending on their specificity and frequency of occurrence. A major topic associated with a supportive topic (e.g., major topic disorders, and supportive topic diseases) was tallied whenever its supportive topic was tallied, whether or not the major topic keyword was explicitly stated in the syllabus. Topic frequency was calculated as the percentage of syllabi containing the topical keywords. In addition, instructional topics were classified as either two- or fouryear college level based on the degree program within which the course was offered. Abundance and frequency of major instructional topics in two-year and four-year course syllabi were compared statistically using Welch's t-test and $\chi^{2}$ homogeneity of proportions test, respectively, at the $\alpha=0.05$ significance level. 
Table 1. Frequency of instructional topics in the online catalog descriptions of 109 collegiate arboriculture courses taught in the U.S. Course descriptions were assessed in early 2008. Only topics with frequency $>20 \%$ are shown.

\begin{tabular}{lcc}
\hline Instructional topics & $\begin{array}{l}\text { Topic frequency in } \\
\text { course descriptions (\%) }\end{array}$ & $\begin{array}{l}\text { Educator importance } \\
\text { perception }(\%)^{\mathbf{z}}\end{array}$ \\
\hline Pruning/Training & 59 & 97 \\
Planting/Transplanting & 48 & 98 \\
Diagnosis/Pest control & 42 & 92 \\
Climbing/Rope work & 38 & 73 \\
Fertilization/Nutrition & 32 & 85 \\
Soil \& water relations & 28 & 93 \\
Structure \& decay identification & 28 & 92 \\
Selection & 23 & 95 \\
\hline
\end{tabular}

${ }^{2}$ Percentage of surveyed arboriculture and urban forestry educators who rated the instructional topic as "very important." From Elmendorf et al. (2005).

Table 2. Frequency of major instructional topic occurrence in the syllabi of 68 collegiate arboriculture courses taught in the U.S. Syllabi were compiled in 2009 and comprise 41 courses from two-year programs and 27 courses from four-year programs.

\begin{tabular}{|c|c|c|c|c|}
\hline \multirow[b]{2}{*}{ Major instructional topics } & \multicolumn{4}{|c|}{ Topic frequency in course syllabi $(\%)$} \\
\hline & Overall & $\begin{array}{l}\text { Four-year } \\
\text { programs }\end{array}$ & $\begin{array}{l}\text { Two-year } \\
\text { programs }\end{array}$ & $P$-value ${ }^{\mathrm{z}}$ \\
\hline Pruning & 85 & 89 & 83 & 0.4970 \\
\hline Disorders & 81 & 89 & 76 & 0.1730 \\
\hline Physiology/Biology & 79 & 82 & 78 & 0.7320 \\
\hline Risks/Hazards & 79 & 85 & 76 & 0.3393 \\
\hline Soils/Nutrition & 75 & 78 & 73 & 0.6677 \\
\hline Selection & 62 & 63 & 61 & 0.8689 \\
\hline Climbing & 57 & 59 & 56 & 0.7965 \\
\hline Water relations & 56 & 59 & 54 & 0.6490 \\
\hline Preservation/Construction & 53 & 59 & 49 & 0.3969 \\
\hline Safety & 53 & 52 & 54 & 0.8839 \\
\hline Tools/Equipment & 53 & 52 & 54 & 0.8839 \\
\hline Appraisals & 32 & 37 & 29 & 0.5029 \\
\hline Benefits/Values of trees & 29 & 22 & 34 & 0.2910 \\
\hline Site assessment & 28 & 30 & 27 & 0.8012 \\
\hline Lightning protection & 27 & 26 & 27 & 0.9342 \\
\hline Identification & 21 & 0 & 34 & 0.0007 \\
\hline Surveys/Inventories & 15 & 11 & 17 & 0.4970 \\
\hline Felling & 13 & 7 & 17 & 0.2498 \\
\hline Certification & 12 & 0 & 20 & 0.0145 \\
\hline Law/Legal issues & 10 & 15 & 7 & 0.3195 \\
\hline
\end{tabular}

${ }^{2}\left(H_{0}: \hat{p}_{i}=\hat{p}_{j}\right)$

\section{RESULTS}

\section{Course Description Assessment}

Keyword analysis of online course descriptions revealed 107 instructional topics within the 109 arboriculture course descriptions that were reviewed. The five most frequent topics (Table 1) were pruning/training (present in 59\% of the course descriptions), planting/transplanting (48\%), diagnosis/pest control (42\%), climbing/rope work (38\%), and fertilization/nutrition (32\%).

\section{Course Syllabus Assessment}

Twenty-two major instructional topics were enumerated in the assessment of arboriculture course syllabi (Table 2). Topic frequency in the syllabi ranged from $10 \%$ for law/legal issues to $85 \%$ for pruning. The majority of these topics occurred in more than half of the syllabi. The top five topics (each present in more than $70 \%$ of the syllabi) were pruning, disorders, physiology/biology, risks/hazards, and soils/nutrition. Although most of the major instructional topics could be readily discerned and categorized, some topics were diffuse in their descriptions and were therefore coupled with supportive topics to facilitate their assessment and provide greater insight on their content. Ten major topics were each associated with two (certification) to nine (disorders) supportive topics (Table 3). For example, diagnosis (disorders major topic) and fertilization (soils/nutrition major topic) were specifically listed in nearly $60 \%$ of the syllabi. Cable/brace and risk assessment (both in the risks/hazards major topic) were also common supportive topics, each listed in about $40 \%$ of the syllabi.

In addition to major and supportive instructional topics, 25 miscellaneous topics were found in the syllabi (Table 4). These topics-ranging from fire management to client relations-appeared in fewer than $10 \%$ of the syllabi. In total, more than 90 major, supportive, and miscellaneous instructional topics were enumerated in the 68 arboriculture course syllabi. On a percourse basis, there were 18 instructional topics on average in each syllabus, ranging from 1 to 38 topics (Table 5). Major instructional topics averaged 10 per syllabi, ranging from 1 to 20 topics. 
There were no significant differences between two- and four-year programs in the average count of instructional topics per course.

Table 3. Overall frequency of major and supportive instructional topics in the syllabi of 68 collegiate arboriculture courses taught in the U.S. Syllabi were compiled in 2009 and comprise 41 courses from two-year programs and 27 courses from four-year programs.

\begin{tabular}{|c|c|c|}
\hline Major instructional topics & Supportive topics & $\begin{array}{l}\text { Topic frequency in } \\
\text { course syllabi (\%) }\end{array}$ \\
\hline Pruning & $\begin{array}{l}\text { ANSI A300 } \\
\text { Training/young trees } \\
\text { Special techniques } \\
\text { Power lines }\end{array}$ & $\begin{array}{r}85 \\
13 \\
13 \\
10 \\
2\end{array}$ \\
\hline Disorders & $\begin{array}{l}\text { Diagnosis } \\
\text { Diseases } \\
\text { Insects/Pests } \\
\text { Plant health care } \\
\text { IPM } \\
\text { Treatment of } \\
\text { Chemical application } \\
\text { Mammals } \\
\text { Turf conflicts }\end{array}$ & $\begin{array}{r}81 \\
59 \\
38 \\
37 \\
31 \\
15 \\
15 \\
10 \\
3 \\
3 \\
\end{array}$ \\
\hline Risks/Hazards & $\begin{array}{l}\text { Cable/Brace } \\
\text { Risk assessment } \\
\text { Support systems } \\
\text { Hazard remediation } \\
\text { Cavity treatment } \\
\text { Wound repair } \\
\text { Guying/Propping } \\
\end{array}$ & $\begin{array}{r}79 \\
41 \\
38 \\
21 \\
19 \\
9 \\
6 \\
2 \\
\end{array}$ \\
\hline Soils/Nutrition & $\begin{array}{l}\text { Fertilization } \\
\text { Nutrients (management of) } \\
\text { Soils (management of) }\end{array}$ & $\begin{array}{l}75 \\
57 \\
37 \\
19 \\
\end{array}$ \\
\hline Planting & $\begin{array}{l}\text { Large/Specimen tree } \\
\text { Mulching } \\
\text { Staking } \\
\text { Trunk wrapping } \\
\text { Site modification } \\
\end{array}$ & $\begin{array}{r}74 \\
15 \\
12 \\
9 \\
6 \\
4\end{array}$ \\
\hline Climbing & $\begin{array}{l}\text { Knots/Ropes } \\
\text { Rigging/Removal } \\
\text { Aerial rescue }\end{array}$ & $\begin{array}{r}57 \\
29 \\
18 \\
4 \\
\end{array}$ \\
\hline Water relations & Irrigation & $\begin{array}{l}56 \\
15 \\
\end{array}$ \\
\hline Safety & $\begin{array}{l}\text { ANSI Z133.1 } \\
\text { Electrical hazards } \\
\text { First aid } \\
\text { OSHA } \\
\text { Underground utility locates }\end{array}$ & $\begin{array}{r}53 \\
9 \\
9 \\
4 \\
2 \\
2 \\
\end{array}$ \\
\hline Tools/Equipment & $\begin{array}{l}\text { Chainsaws } \\
\text { Chippers } \\
\text { Aerial lifts } \\
\text { Stump grinders } \\
\text { Skidders }\end{array}$ & $\begin{array}{r}53 \\
27 \\
12 \\
9 \\
7 \\
2\end{array}$ \\
\hline Certification & $\begin{array}{l}\text { ISA } \\
\text { State }\end{array}$ & $\begin{array}{r}12 \\
10 \\
2\end{array}$ \\
\hline
\end{tabular}

Table 4. Overall frequency of miscellaneous instructional topics in the syllabi of 68 collegiate arboriculture courses taught in the U.S. Syllabi were compiled in 2009 and comprise 41 courses from two-year programs and 27 courses from four-year programs.

\begin{tabular}{lc}
\hline Instructional topics & $\begin{array}{c}\text { Topic frequency in } \\
\text { course syllabi (\%) }\end{array}$ \\
\hline Business issues & 9 \\
Report writing/estimates & 9 \\
Appreciation for trees & 7 \\
History & 7 \\
Nursery practices & 7 \\
Organizations & 6 \\
Client relations & 4 \\
Ethical issues & 4 \\
Girdling roots/collar excavation & 4 \\
Professional skills development & 4 \\
Current topics & 3 \\
Grounds maintenance & 3 \\
Personnel management & 3 \\
Storm response/damage & 3 \\
Vertical/Radial mulching & 3 \\
Christmas tree production & 2 \\
Consulting & 2 \\
Fire management & 2 \\
Grafting/Budding & 2 \\
Literature awareness & 2 \\
Planter box bedding & 2 \\
Supervisory duties & 2 \\
Volunteer coordination & 2 \\
Windbreaks/Shelterbelts & 2 \\
Winterizing plants & 2 \\
\hline
\end{tabular}

\section{DISCUSSION}

\section{Course Content Versus Educator Attitudes}

Comparing instructional topics described in course catalogs to educator attitudes surveyed by Elmendorf et al. (2005) suggests that arboriculture course content and educator attitudes are not fully aligned. For example, despite being the secondmost important topic ranked by instructors, pruning (considered "very important" by $97 \%$ of instructors) appeared in only $59 \%$ of the course descriptions. The other four topics from the educator survey top five (all considered "very important" by $>90 \%$ of instructors) appeared in fewer than half the course descriptions: planting (48\%), soil \& water relations (28\%), structure \& decay identification (28\%), and selection (23\%). Based on the course descriptions, there appears to be a discrepancy between what is being taught in arboriculture courses and what is considered important by arboriculture instructors.

In contrast to the course descriptions, the greater topical detail found in the course syllabi revealed that the majority of surveyed collegiate arboriculture courses in the U.S. provide instruction on the topics deemed most important by educators in the Elmendorf survey. Specifically, the instructors' top five topics were all present in more than half of the syllabi, and most were in more than three-fourths of the syllabi. In fact, only planting (rated "very important" by $98 \%$ of respondents) and selection (95\% rating) were present in fewer than $75 \%$ of the syllabi, just missing the mark at $74 \%$ and $62 \%$, respectively. These arguably minor disparities are likely a consequence of arboriculture courses focusing on the maintenance and management of trees after their establishment in the landscape. 
Although this comparison of educator attitudes and course content suggests there are some inconsistencies in arboriculture education, several aspects of this comparison may inflate the observed disparities. First, online course descriptions are not highly reliable instruments for assessing the breadth of instructional topics. By definition, a course description is a concise statement of course content that only mentions major instructional topics. In fact, many colleges have explicit limitations on the length of course descriptions provided by instructors. Moreover, course descriptions are likely to be outdated because they are often crafted when a course is first offered and may not be revised as frequently as a course syllabus, particularly if the official course description is subject to a stringent university approval system. While both of these factors may be at play, the authors of this study cannot attribute differences in topic frequency between course descriptions and syllabi to either the brevity or the timeliness of course descriptions.

While course descriptions alone cannot fully gauge arboriculture course content, when combined with the more detailed and frequently updated course syllabi, these findings provide a clearer picture of what is being taught in arboriculture classes today. Moreover, these findings suggest that arboriculture instructors should ensure that their course catalog descriptions are an accurate reflection of their course content. At a time when many collegiate arboriculture programs are challenged to maintain enrollment, instructors must capitalize on every means (particularly online) to market their courses and attract new students. An accurate, wellwritten course description is an important part of this marketing.

A second limitation of this comparative assessment is the origin of the data. The scope of the Elmendorf survey was much broader, encompassing both arboriculture and urban forestry educators. Their survey sample comprised 136 educators (out of 192 requests) in contrast to the 59 educators (out of 73 requests) sampled in the current study. Because urban forestry is a broader discipline than arboriculture, respondents to the educator survey likely rated a broader suite of educational topics as important. Moreover, the educators were asked to rate the importance of topics to a comprehensive education, not to a single course. Undoubtedly, many of the arboriculture courses assessed here are part of a curriculum that also includes courses on important topics-such as plant identification - that are foundational to the course but not included in the course per se. Finally, there is an implicit assumption that the course syllabus is an accurate reflection of course content. As with course descriptions, syllabi undoubtedly show considerable variation in their itemization of course contentsome are a single page summation of course activities and grading, while others are a multi-page document describing course content on a daily basis. Thus, syllabi can also underestimate the breadth of instructional topics taught in arboriculture courses.

\section{Two-year Versus Four-year Programs}

Major instructional content of arboriculture courses was very similar between two- and four-year colleges (Table 2). Two exceptions were the presence of tree identification as well as ISA or state certification in the two-year program courses-neither of which appeared in course syllabi of four-year programs. This finding may reflect differences in the educational missions of two- and four-year institutions. In addition to offering associate degrees in arboriculture, many technical and commu- nity colleges offer arboriculture certificates targeted to working professionals and other non-traditional students. Thus, tree identification may be incorporated into an arboriculture course for students in these accelerated programs, whereas students in an associate or baccalaureate degree program may take a separate dendrology or plant identification course. Further, ISA or state certification may be prominent themes of some vocational arboriculture programs that emphasize employment eligibility as an explicit course objective or institutional mission.

\section{Trends in Course Content}

The breadth of instructional topics gleaned from arboriculture course syllabi encompasses "cradle-to-grave" tree management, with greater emphasis placed on their preservation (e.g., disorder management and construction protection) than on their demise (e.g., rigging and felling). Frequent mention of tree physiology/biology, disorder diagnosis, soils/nutrition, and water relations suggests that these courses are well-founded in the basic scientific principles underpinning sound arboricultural practices. There is also evidence that arboriculture instruction is progressive and responsive to scientific discoveries and advancements in technology. For example, chemical application was mentioned in only $10 \%$ of syllabi, whereas integrated pest management and plant health care were found in $15 \%$ and $31 \%$ of syllabi, respectively. Cavity treatment - once considered an essential skill for arborists - was referred to in less than $10 \%$ of syllabi (and none of those referred to cavity filling).

What remains unclear is whether these instructional topics are delivered in a theoretical or applied context. One may speculate that theory prevails. For example, while pruning appeared in $85 \%$ of the syllabi, the term equipment (i.e., tools for performing pruning) appeared in only 53\%. Taking a closer look at the specific equipment for which instruction is provided, chainsaw was the most common implement mentioned, yet it appeared in only $26 \%$ of syllabi. Moreover, while one might safely assume that nearly all arboriculture operations have at least one brush chipper that is utilized on a daily basis, barely $10 \%$ of syllabi mentioned training in their use. However, infrequent mention of training on such equipment may not equate to intentional exclusion in course design. The costs of purchasing, maintaining, and insuring equipment - not to mention liability issues that are difficult for academic institutions to address - may be the limiting factors. In addition, many institutions may place emphasis on science and management in their arboriculture courses and opt to develop practical skills through internships and extracurricular activities rather than through formal coursework.

Although safety should always be a paramount consideration in the arboriculture profession, the term safety occurred in just over half of the syllabi; likewise, ANSI Z-133.1 (the American National Standard for Arboricultural Operations - Safety Requirements) was referenced in fewer than $10 \%$. Though many courses may not deal directly with the more hazardous elements of arboriculture, consideration must be given to the production arboriculture positions many students will enter upon graduation or during summer internships. It is never too early to emphasize safety, and that emphasis should be an integral component of every arboriculture course.

Collegiate arboriculture courses appear to be preparing students for diverse occupations that go beyond production arbori- 
culture. Nearly one-third of the syllabi mentioned tree values \& benefits, suggesting that students are also preparing for careers in public education or governmental affairs. Others may be preparing for careers in municipal arboriculture-surveys \& inventories were found in $15 \%$ of the syllabi. While working as a consulting arborist typically requires several years of field experience, some students are building knowledge on tree appraisals (32\% of syllabi) and arboriculture law \& legal issues (10\% of syllabi). A few courses even address topics related to employee character, such as ethical issues, client relations, and professional skills development.

The most recent survey of employers and practicing professionals regarding educational needs that were identified was from the 1980s (McPherson 1984). The practice of arboriculture is rapidly changing. New demands are being placed on landscapes and trees to provide ecosystem services (Nowak 2006), and practicing arborists may be consulting on topics well beyond the scope of traditional arboriculture. To the extent that online course descriptions are a lagging indicator of arboriculture course content, there is some evidence from this assessment that course content is evolving. Course descriptions are typically created when a course is first taught and are only updated during major shifts in course content. As a result, they can provide some indication of past course content. For example, although pruning was the most prevalent topic in both course descriptions and syllabi, structure \& decay identification appeared in approximately half as many course descriptions as pruning. In contrast, the synonymous topical keyword (risks/hazards) was nearly as common as pruning in syllabi ( $80 \%$ versus $85 \%$ ), suggesting that tree risk management may be receiving more attention in arboriculture courses now than in the past. However, since the study authors were unable to compare past syllabi with current syllabi, this notion cannot be confirmed.

\section{CONCLUSIONS}

To date, limited research has been performed in the United States that evaluates arboriculture education. As the profession prepares for the future, it may be prudent to follow the basic planning process espoused by Miller (1997): What do we have? What do we want? How do we get what we want? We already have a fair notion of what we want - more arborists with the knowledge and skills to creatively and effectively manage trees in a fast-paced, 21 st century economy. The more elusive question is "what do we have?" While this course assessment has shed light on collegiate arboriculture education, we still do not know to what depth course topics are being taught or how conducive instruction is to student learning. Appearance of a topic on a course syllabus does not always equate to its instruction. Likewise, the absence of a topic on a syllabus does not equate to it not being taught. A syllabus may simply fall short of completely encapsulating course content, or an instructor may take advantage of "teachable moments" during lecture or lab to augment the primary subject matter. Until one has a more comprehensive understanding of the delivery and quality of collegiate arboriculture education, they cannot answer the final question in the planning process: How do we get what we want? Assessing these metrics among the hundreds of continually evolving institutions and instructors who educate future arborists may be a task beyond the scope of traditional survey research methods. This aim might be better achieved by engaging arboriculture educators and employers in sharing and discussing professional practice and future challenges in a scholarly setting.

Despite these limitations, the content of collegiate arboriculture courses in the U.S. appears to be consistent with educators' instructional priorities, and there are negligible differences in course content between two- and four-year programs. Course content has a tendency to lean toward skills directly associated with landscape tree care, but it also includes topics relevant to arboriculture in a broader context. There is an apparent shortage of instruction on arborist safety. Collegiate arboriculture programs may have an opportunity to better serve the industry in this regard by including formal instruction on equipment use and safe work practices. Although academic institutions are limited in their ability to provide applied instruction on certain higher-risk or equipment-intensive duties, the scarcity of safety as an emphasis in instruction is difficult to justify. Even if hands-on safety practices are not included in courses, risk and safety management could be incorporated into curricula. However, this course review was limited to courses with arboriculture in their titles. In the context of a larger arboriculture curriculum, instruction on key tree care topics could take place in multiple courses that may or may not bear the arboriculture title, thus giving the impression that subject matter was absent.

Acknowledgments. The authors wish to thank Tchukki Andersen of Tree Care Industry Association and Mark Noark of The Davey Tree Expert Company for their assistance in identifying U.S. institutions of higher education where collegiate arboriculture courses were likely to be taught. The authors also thank the numerous arboriculture educators who provided their course syllabi for this educational assessment.

Table 5. Instructional topic occurrence in the individual syllabi of 68 collegiate arboriculture courses taught in the U.S. Syllabi were compiled in $\mathbf{2 0 0 9}$ and comprise $\mathbf{4 1}$ courses from two-year programs and $\mathbf{2 7}$ courses from four-year programs.

\begin{tabular}{|c|c|c|c|c|}
\hline \multirow[b]{2}{*}{ Statistic } & \multicolumn{2}{|c|}{$\begin{array}{c}\text { All instructional topics } \\
\text { (\#/syllabus) }\end{array}$} & \multicolumn{2}{|c|}{$\begin{array}{l}\text { Major instructional } \\
\text { topics (\#/syllabus) }\end{array}$} \\
\hline & $\begin{array}{l}\text { Four-year } \\
\text { programs }\end{array}$ & $\begin{array}{l}\text { Two-year } \\
\text { programs }\end{array}$ & $\begin{array}{l}\text { Four-year } \\
\text { programs }\end{array}$ & $\begin{array}{l}\text { Two-year } \\
\text { programs }\end{array}$ \\
\hline Minimum value & 6 & 1 & 3 & 1 \\
\hline Average & 19 & 17 & 10 & 10 \\
\hline Standard deviation & 8 & 8 & 3 & 5 \\
\hline Maximum value & 38 & 33 & 15 & 20 \\
\hline$P$-value $\left(\mathrm{H}_{0}: \mu_{1}=\mu_{2}\right)$ & \multicolumn{2}{|c|}{0.2671} & \multicolumn{2}{|c|}{0.8132} \\
\hline
\end{tabular}




\section{LITERATURE CITED}

Andresen, J.W. 1977. University arboriculture education in North America. Journal of Arboriculture 3:27-32.

Andresen, J.W. 1981. Current trends in North American university arboricultural education. Journal of Arboriculture 7:253-265.

Andresen, J.W., and B.M. Williams. 1975. Urban forestry education in North America. Journal of Forestry 73:786-790.

Bureau of Labor Statistics. 2009. Occupational Outlook Handbook, 2010-2011 Edition. Accessed 4/15/2010. <http://www.bls.gov/oco/ ocos172.htm>

Deneke, F.J. 1978. Urban forestry education. Journal of Arboriculture 4:154-156.

Elmendorf, W., T. Watson, and S. Lilly. 2005. Arboriculture and urban forestry education in the United States: results of an educators survey. Journal of Arboriculture 31:138-149.

Green, C.C. 2006. Forestry education in the United States. Issues in Science and Technology Librarianship 46 (Suppl. 1). Accessed 7/15/2010. <http://www.istl.org/46-supp/article7.html>

Hildebrandt, R.E., D.W. Floyd, and K.M. Koslowsky. 1991. The Status of Urban Forestry Education in the 1990s. In: Proceedings of the 1991 Society of American Foresters National Convention: 464-470.

Hildebrandt, R.E., D.W. Floyd, and K.M. Koslowsky. 1993. A review of urban forestry education in the 1990s. Journal of Forestry 91(3):40-42.

International Society of Arboriculture (ISA). 2008. International Society of Arboriculture - Search for Degrees. Accessed 3/15/2008. <http:// www.isa-arbor.com/students/degreeSearch.aspx>

King, G. 1977. Principles of education in arboriculture. Journal of Arboriculture 3:137-140.

McPherson, G. 1984. Employer perspectives on arboriculture education. Journal of Arboriculture 10:137-142.

Miller, R.W. 1994. Urban forestry education: traditions and possibilities. Journal of Forestry 92:26-27.

Miller, R.W. 1997. Urban Forestry: Planning and Managing Urban Greenspaces. 2nd Ed. Prentice Hall, Englewood Cliffs, NJ.

Nowak, D.J. 2006. Institutionalizing urban forestry as a "biotechnology" to improve environmental quality. Urban Forestry \& Urban Greening 5(2):93-100.

O’Bryan, C.M., T.J. Straka, S.R. Templeton, and J.D. Caldwell. 2007. Economic patterns in U.S. arboriculture. Arboriculture \& Urban Forestry 33(4):292-299.

Parkes, J., and M.B. Harris. 2002. The Purposes of a Syllabus. College Teaching 50(2):55-61.

Penn-Del Chapter of ISA. 2001. Arboriculture: The State of the Industry. The Pennsylvania Delaware Chapter of the International Society of Arboriculture, Bedminster, PA. 10 pp.

Rodbell, P.D. 1993. Back to the books. Urban Forestry 12(6):11.

Ryan, D.P., III. 1979. S.U.N.Y. degree in arboriculture. Journal of Arboriculture 5:78-81.

Society of American Foresters. 2010. Accreditation Handbook - Standards, Procedures, and Guidelines for Accrediting Educational Programs in Professional Forestry. Accessed 7/7/2010. <http://www. safnet.org/education/AccHdbk2010.pdf>

Sydnor, T.W. 1997. Education of an urban or community forestry work force. Arborist News 7:9-11.

Tree Care Industry Association (TCIA). 2008. Colleges and Universities with Arboriculture Programs. Accessed 3/15/2008. <http://www. treecareindustry.org/Public/product_careers_educational_links.htm>
P. Eric Wiseman (corresponding author)

Department of Forest Resources \& Environmental Conservation Virginia Tech

228 Cheatham Hall

Blacksburg, VA 24061-0324, U.S.

pwiseman@vt.edu

Joseph W. Hoffman

Mid-State Technical College

500 32nd Street North

Wisconsin Rapids, WI 54494, U.S.

joe.hoffman@mstc.edu

Susan D. Day

Departments of Forest Resources \& Environmental Conservation and Horticulture

Virginia Tech

310 Cheatham Hall

Blacksburg, VA 24061-0324, U.S.

sdd@vt.edu

Terry L. Clements

School of Architecture \& Design

Virginia Tech

122 Burruss Hall

Blacksburg, VA 24061-0190, U.S

tclement@vt.edu 
Résumé. Les habilités professionnelles et l'expertise demandées chez les arboriculteurs praticiens sont plus grandes que par le passé et plusieurs employeurs ainsi que les enseignants croient qu'une scolarité de base plus importante s'avère nécessaire pour la formation des futurs professionnels sur le terrain. Même si des récentes enquêtes ont permis d'identifier d'importants sujets d'instructions qui sont critiques pour les futurs arboriculteurs, aucune évaluation sur le comment ces sujets sont traités dans les programmes au sein des collèges et des universités n'a été faite. Le présent article traite d'une évaluation du syllabus de 68 cours en arboriculture qui sont donnés dans des institutions supérieures d'enseignement aux États-Unis. Les sujets les plus communs d'enseignement dans un syllabus de cours en arboriculture sont l'élagage (85\%), les désordres (81\%), la physiologie/biologie (79\%), les risques/dangers $(79 \%)$ et la nutrition des sols $(75 \%)$. Le choix des arbres et la plantation, des sujets qui ont été identifiés par les enseignants et les employés du secteur public comme les plus importants sujets d'enseignement lors d'études précédentes, ont été retrouvés dans seulement $62 \%$ et $74 \%$ respectivement des syllabus de cours. La sécurité était traitée dans seulement $53 \%$ des syllabus. Le contenu des syllabus était relativement similaire parmi les institutions délivrant la formation en deux ou quatre ans, et ce même si l'identification des arbres et la certification des arboriculteurs étaient mentionnées plus fréquemment au sein des syllabus de formation sur deux ans. Les enjeux de la formation en arboriculture ainsi que les implications pour les employeurs et les professionnels sont discutés.

Zusammenfassung. Die professionellen Fähigkeiten und Fachkunde, die von praktizierenden Arboristen gefordert werden, ist heute größer denn je in der Vergangenheit. Viele Arbeitgeber und Ausbilder glauben, daß eine höhere Ausbildung einegroße Rolle bei der Ausbildung künftiger Professioneller in diesem Bereich spielen wird. Obwohl kürzlich durchgeführte Umfragen Hauptthemenschwerpunkte für die Ausbildung künftiger Arboristen identifiziert haben, gibt es keine Prüfung, ob diese Themen am College unterrichtet werdenund in den Universitätsprogrammen erhältlich sind. Der vorliegende Artikel beschäftigt sich mit einer Prüfung der Lehrinhalte von 68 Kursen zur Arboristik, die an höheren Ausbildungsstätten in den Vereinigten Staaten angeboten und unterrichtet werden. Die meistgenannten Schwerpunkte in den Lehrplänen der Arboristikkurse über zwei oder vier Jahre Ausbildung sind: Schnitttechnik (85\%), Krankheiten (81\%), Physiologie/Biologie (79\%), Risiken/Gefahren (79\%) und Boden/Pflanzenernährung (75\%). Baumpflanzung und Baumauswahl, zwei Schwerpunkte, die von Ausbildern und öffentlichen Arbeitgebern in vorangegangenen Umfragen zu den wichtigsten Schwerpunkten gezählt wurden, fanden sich nur zu 74\% bzw. 62 $\%$ in den Lehrplänen wieder. Arbeitssicherheit wurde nur in $53 \%$ der Lehrpläne integriert. Der Lehrplanaufbau und -inhalt war beiden zweiund vierjährigen Kursen identisch, obwohl Baumartenkenntnis und Arboristenzertifikation in den zweijährigen Kursen öfter genannt wurden. Der Trend in der Ausbildung zum Arboristen und die Implikationen für Ausbilder und Arbeitgeber werden hier diskutiert.

Resumen. Las herramientas profesionales y expertas demandadas por los arboristas son ahora mayores que en el pasado, y muchos empleados públicos y educadores creen que una eduación alta juega un papel en los futuros profesionales en este campo. A pesar que las encuestas recientes han identificado tópicos principales en edudación importantes para los futuros arboristas, no existe evaluación de si estos tópicos están disponibles en los programas de las universidades. El siguiente reporte es una evaluación de 68 resúmenes de cursos de arboricultura de instituciones de eduación superior de los Estados Unidos. Los tópicos de instrucción más comunes observados en instituciones de dos y cuatro años fueron poda (85\%), desórdenes (81\%), selección/biología (79\%), riesgos/peligros (79\%), y suelos/nutrición (75\%). La selección y plantación del árbol, tópicos identificados por los educadores y empleados del sector público en estudios previos entre las áreas más importantes, fueron encontrados solamente en $74 \%$ y $62 \%$ de los cursos, respectivamente. La seguridad fue mencionada en solamente 53\% de los programas. El contenido de los programas fue similar en las instituciones de dos y cuatro años, sin embargo la identificación y la certificación fueron mencionados más frecuentemente en programas de instituciones de dos años. Se discuten las tendencias en la educación en arboricultura e implicaciones para los empleadores y profesionales. 
Appendix: Colleges in the contiguous U.S. contacted in 2008 to request syllabi for their arboriculture courses. Of these 73 colleges, instructors at 59 colleges (denoted by *) provided syllabi for 68 total courses. Colleges are grouped by the local chapter of the International Society of Arboriculture in which they geographically reside.

\section{Florida Chapter}

Palm Beach Comm. College

Univ. of Florida*

Illinois Chapter

College of DuPage*

Illinois Central College*

Joliet Junior College*

Kishwaukee College*

Univ. of Illinois - Urbana

Western Illinois Univ.*

\section{Indiana Chapter}

Purdue Univ.*

Vincennes Univ.

\section{Kentucky Chapter}

No colleges identified

Michigan Chapter

Andrews Univ.*

Oakland Comm. College*

\section{Mid-Atlantic Chapter}

Univ. of Maryland*

Tidewater Comm. College*

Virginia Tech*

Virginia Western Comm. College*

\section{Midwestern Chapter}

Kansas State Univ.*

Minot State Univ. - Bottineau*

North Dakota State Univ.*

Northeast Iowa Comm. College*

Oklahoma State Univ.*

South Dakota State Univ.

Southeast Technical Institute*

\section{Minnesota Chapter}

Central Lakes College*

Hennepin Technical College

Univ. of Minnesota*

Univ. of Minnesota - Crookston*

New England Chapter

Naugatuck Valley Comm. College*

Southern Maine Comm. College*

Unity College*

Univ. of Massachusetts - Amherst*

New Jersey Chapter

Bergen Comm. College

Rutgers Univ.

New York Chapter

Paul Smith's College*

Ohio Chapter

Kent State Univ.*

Ohio State Univ. - ATI*

Pacific Northwest Chapter Clackamas Comm. College*

College of Southern Idaho*

Linn Benton Comm. College*

South Seattle Comm. College*

Spokane Comm. College*

Penn-Del Chapter

Ambler College (Temple Univ.)*

Delaware Valley College*

Penn State Univ.*

Penn State Univ. - Mont Alto*

Rocky Mountain Chapter

Front Range Comm. College*
Southern Chapter

Auburn Univ.

Brunswick Comm. College*

Central Piedmont Comm. College*

Middle Tennessee State Univ.

Nashville State Comm. College

Sandhills Comm. College*

Southeastern Louisiana Univ.

Southern Univ. and A\&M College

Tennessee Technological Univ.*

\section{Texas Chapter}

Palo Alto College*

Stephen F. Austin State Univ.*

Tarrant County College*

Texas A\&M Univ.*

Utah Chapter

Brigham Young Univ.*

Western Chapter

Cal Poly Univ. - Pomona*

Cal Poly Univ. - San Luis Obispo*

College of the Desert*

College of Southern Nevada*

Cuyamaca College*

Diablo Valley College

Merritt College

Mount San Antonio College*

Wisconsin Chapter

Blackhawk Technical College*

Mid-State Technical College*

Univ. of Wisconsin*

Univ. of Wisconsin - River Falls*

Univ. of Wisconsin - Stevens Point* 